\title{
Characterization of Coal obtained from the Sahelian Regions of Nigeria and Niger Republic
}

\section{1'SAMAILA, MB; ${ }^{2}$ MUHAMMAD, BG; ${ }^{1}$ ADAM, AH; ${ }^{3}$ MOUMOUNI, A; ${ }^{* 2}$ BELLO, $S$}

\author{
${ }^{l}$ Department of Pure and Industrial Chemistry, Umaru Musa Yar'adua University, Katsina, Nigeria \\ ${ }^{* 2}$ Department of Physics, Umaru Musa Yar'adua University, Katsina. \\ ${ }^{3}$ Faculty of Science, Dandicko Dankulodo University, Maradi, Niger Republic. \\ "Correspondence Email \& Phone: suleiman.bello@umyu.edu.ng; +2348166791940
}

\begin{abstract}
Coal is the most widely available fossil fuel energy resource. This work was carried out to compare the composition, Sulphur content and combustibility of the Nigerian and Nigerien coal samples. Coal samples were obtained from Enugu, Nigeria, Tahuoa and Agadez of Niger Republic. Results indicated that, coal samples from Tahuoa $(\mathrm{RS} / \mathrm{T})$ and coal from Agadez (RS/A) have highest percentage of fixed carbon $(71.2 \%$ and $61.0 \%$ for Tohoua and Agadez respectively), while the coal from Enugu (RS/E), Nigeria, have the least percentage (49.2\%) which made them to have high fuel ratio enabling them to be more combustible, as determined by the thermal efficiency test. The study revealed that the coal from Niger is of higher grade with ease of combustion and less smoke as found in the combustibility test.
\end{abstract}

DOI: https://dx.doi.org/10.4314/jasem.v24i2.16

Copyright: Copyright $(2020$ Samaila et al. This is an open access article distributed under the Creative Commons Attribution License (CCL), which permits unrestricted use, distribution, and reproduction in any medium, provided the original work is properly cited.

Dates: Received: 16 November 2019; Revised: 11 January 2020; Accepted: 22 February 2020

Keywords: Coal, Sulphur, fuel ratio, carbon content, combustion and thermal efficiency.

Despite the abundant resources, the country is in short supply of electricity. The presence of energy resources should expectedly catalyze economic growth, technological advancement and creates better living standards for the people. Access to energy, specifically electricity, is an impetus for economic and social development. But in Nigeria, lack of policy implementation, corruption and rigid government control of electricity generation has caused a dismal failure of achieving reliable electric power supply. The electricity needed to power and grow the economy, drive local development and tackle urban and rural poverty is simply inadequate or not available at all. A well-managed electric power sector has profound benefits to the economy (Ogunsola, 1990). Coal is the most widely available fossil fuel energy resource. Unlike gas and oil it is widely distributed, both geographically and in terms of resource ownership. Its abundance provides energy security to many countries because its supply will last significantly longer than gas or oil. It was predicted that coal will continue to play a very significant role in world primary energy demand well into the future. It has been estimated that there are over 860 billion tonnes of proven coal reserves worldwide. This means that there is enough coal to last us at least 118 years at current rates of consumption (Obaje, 2009). In contrast, proven oil and gas reserves are equivalent to around 46 and 57 years at current consumption levels. However, reserve estimates vary. Worldwide, potential coal resources dwarf proven reserves and many analysts believe that coal could last considerably longer. Some deposits are estimated to have as much as 400 years of production remaining and new technologies for utilizing coal resources, such as underground coal gasification, are likely to boost coal's future role in energy supply even further. Coal reserves are available in almost every country with recoverable reserves in around 70 countries (Fawkes, 2005). The largest reserves are in the USA, Russia, China and India. Importantly, many countries with significant energy poverty challenges also have significant coal reserves. The ability to utilize domestic coal reserves to address problems of energy access reduces reliance on imported energy, particularly oil and gas which are often sourced from unreliable and unstable markets. Utilization of coal to complement renewable energy sources, particularly wind, reduces the risk of an intermittent supply. The Sulphur content of coal varies considerably with the nature and origin of the fossil deposits. Sulphur in coal is present in both inorganic and organic forms. The inorganic Sulphur in coal consists predominantly of sulphide (pyrite $\left(\mathrm{FeS}_{2}\right)$, sphalerite $(\mathrm{ZnS})$, Galena $(\mathrm{PbS})$, Arsenopyrite $(\mathrm{FeAsS})$ ) and Sulphates. (Barite $\left(\mathrm{BaSO}_{4}\right), \quad$ Gypsum $\left(\mathrm{CaSO}_{4} \cdot 2 \mathrm{H}_{2} \mathrm{O}\right)$, Anhydrite $\left(\mathrm{CaSO}_{4}\right)$, and a number of Iron Sulphates and others (Constanti et al., 1994), Pyrite is generally the predominant inorganic Sulphur in coal. Pyritic sulfur occurs in coal as grains of the mineral pyrite $\left(\mathrm{FeS}_{2}\right)$. Much of the pyrite in coal was formed by reactions of iron and sulfur in water in the coal swamp or in water washing through the coal as it accumulated. The amount of pyritic sulfur in coal is highly variable, depending on the local geologic circumstances, it may range from about $0.5 \%$ to $7 \%$ (Klein et al., 1994). Organic sulfur may be a remnant of sulfur in proteins 
in the original plant material that was converted to coal, or it may have been chemically bonded to the coalifying organic matter by bacterial action. The utilization of coals for both energy production and various coal conversion processes is limited by the presence of Sulphur in the coal. The high Sulphur dioxi-de emissions caused by the utilization of coals as a major fossil fuel leads to worldwide environmental problems. When coal is burnt, its Sulphur combines with oxygen to form Sulphur dioxide $\left(\mathrm{SO}_{2}\right)$, which can contributes to pollution and acid rain. Acid rain resulting from $\mathrm{SO}_{2}$ has a harmful effect on agriculture and destroys the ecological balance (Blake and Hartage, 1986). The presence of Sulphur in coal also reduces the quality of metallurgical coal (Klein et al., 1994). Therefore, this work was carried out to compare the composition, Sulphur content and combustibility of the Nigerian and Nigerien coal samples.

\section{MATERIALS AND METHOD}

Sampling and Sample Preparation: The coal samples were obtained from Anou Araren (Agadez region) and Salkadamna (Tahoua region) mining sites in Niger republic, and Enugu, Nigeria. The Nigerian and Nigerien coal samples were obtained from designated areas directly. Each sample was wrapped in polythene bag and labeled appropriately before taken to the laboratory for further analysis. The samples were crushed with hammer to ground coarse-fine grain particles and separately sieved using $212 \mu \mathrm{m}$ aperture to obtain particle size of 80 meshes. The samples were transferred into separate air-tight rubber containers, labeled appropriately and kept for further use. All chemicals were purchased and used without further purification.

Determination of the coal composition by proximate analysis: Proximate analysis for moisture, ash contents, volatile matter, fixed carbon and fuel ratio were carried out on the samples according to standard methods of the American Standard of Testing and Measurement (ASTM, 1979).

Determination of Sulphate: Determination of Sulphate was carried out in accordance to the standard methods used for the determination of various forms of Sulphur in coal specified in ASTM D2492- 02 (2007). It was based on the principle that Sulphate Sulphur is soluble in dilute hydrochloric acid solution. $1.0 \mathrm{~g}$ each of the coal samples was weighed in a beaker and $0.05 \mathrm{M}$ Hydrochloric acid added, it was shaken and allowed to stand for 30mins. The mixture was filtered and the residue washed with distilled water. Ammonium hydroxide solution was added to the filtrate followed by barium chloride. The precipitate formed was dried at $70^{\circ} \mathrm{C}$ for 5 mins and weighed.

Determination of Inorganic (Pyritic form of Sulphur): Nitric acid dissolves Sulphate and pyritic Sulphur quantitatively and reacts with organic Sulphur only slightly. Pyrite Sulphur however can be determined accurately by noting the quantity of iron extracted by dilute hydrochloric acid and subtracting this from the iron extracted by nitric acid, the difference being the iron present as pyrite iron (FeS), from which the equivalent quantity of pyrite Sulphur can be calculated. (ASTM, 2007). 1.0M Nitric acid was added to $1.0 \mathrm{~g}$ of each sample and filtered. $30 \%$ Hydrogen peroxide was added to decolorize the filtrate, followed by addition of ammonium hydroxide and barium chloride solutions. The mixture was filtered, and the residue dried at $70^{\circ} \mathrm{C}$.

Determination of Total Sulphur: The Eschka method was used to determine total Sulphur in the coal. $1.0 \mathrm{~g}$ of each coal sample and Eschka mixture (two parts by mass of magnesium oxide and one part of anhydrous sodium carbonate) were mixed and heated together at a temperature of $800^{\circ} \mathrm{C}$ for 5mins. The Sulphur compounds evolved during combustion reacted with magnesium oxide and sodium carbonate under oxidizing conditions, both were converted to Magnesium Sulphate and sodium Sulphate. The products were extracted with dilute hydrochloric acid followed by Barium chloride solution to precipitate Barium Sulphate. The precipitates were filtered, ashed at $500^{\circ} \mathrm{C}$ for 1 hour and weighed.

Determination of organic Sulphur: Organic Sulphur was obtained by subtracting the combined percentages of Sulphate Sulphur and pyritic Sulphur from the total Sulphur determined.

Combustibility Test: $25 \mathrm{~g}$ of the block- form coal sample was taken into an iron stove and ignited. It was fanned until it glows. A calorimeter containing $100 \mathrm{~cm}^{3}$ of water was dipped into a pot containing $300 \mathrm{~cm}^{3}$ of water. A thermometer was inserted through the opening in the calorimeter. The pot was placed on the iron stove containing the ignited coal sample and the time was recorded. The water was heated until boiling commences. The time and temperature at boiling were recorded. The experiment was performed at the same time for the three samples. The initial time was subtracted from the final to get the actual time of the boiling.

\section{RESULTS AND DISCUSSION}

Composition of the coal samples: The result of proximate analysis of the three coal samples (Table 1) shows that coal from Tahoua has lowest percentage of moisture content $(1.1 \%)$, while that of Enugu (RS/E) has the highest percentage of moisture content $(4.6 \%)$. Moisture in coal is an undesirable property as it decreases the burning efficiency of the coal. In the case of ash content, coal from Agadez (RS/A) has highest percentage of ash content (15.0\%) and RS/E has the least percentage of ash content $(6.0 \%)$. Ash is also undesirable as it reduces combustion. Fixed 
carbon and volatile matter are desirable factors in coal combustion, and all the three coal samples have high percentages of the two factors. RS/T had the highest percentage of fixed carbon $(71.2 \%)$ and is therefore expected to burn more evenly with hot flames, followed by RS/A (61.0\%) and lastly RS/E (49.2\%). The coal from Enugu had the highest percentage of volatile matter $(40.2 \%)$ and is expected to burn more evenly with smoky flames, followed by RS/A (22\%) and lastly $\mathrm{RS} / \mathrm{E}$ which has the least percentage $(13.2 \%)$.

Table 1: Composition of the coal samples

\begin{tabular}{lllll}
\hline Sample & $\begin{array}{l}\text { Moisture } \\
\text { content } \\
\text { (MC) } \%\end{array}$ & $\begin{array}{c}\text { content } \\
\text { (AC) } \%\end{array}$ & $\begin{array}{c}\text { Volatile } \\
\text { matter } \\
\text { (VM) } \%\end{array}$ & $\begin{array}{l}\text { Fixed } \\
\text { carbon }\end{array}$ \\
\hline RS/A & 1.6 & 15.0 & 22.0 & 61.0 \\
RS/T & 1.1 & 14.1 & 13.2 & 71.2 \\
RS/E & 4.6 & 6.0 & 40.2 & 49.2 \\
\hline
\end{tabular}

The fuel ratio and thermal efficiency: The fuel ratio (as shown in figure 1) of the coal samples shows that the coal from Tahoua (RS/T) has the highest ratio of 5.39, this is due to high percentage of fixed carbon content and lower volatile matter. This indicated that, it will be more combustible. $\mathrm{RS} / \mathrm{E}$ has the least fuel ratio of 1.22 hence, least combustible. Both RS/T and RS/A showed good quality fuel ratio, hence, more efficient in burning with less smoke. Thermal efficiency test result of the coal samples (figure 2) shows that the coal sample from Tahoua (RS/T) had the minimum time of 26 mins to boil $100 \mathrm{ml}$ of water. This could be attributed to its higher fixed carbon content and lower percentage of volatile matter. This result agrees with the calculated fuel ratio of the samples (fig 1). While the coal sample from Enugu (RS/E) has the maximum time (37mins) to boil same volume of water. This in turn could be as a result of its lower fixed carbon content and higher percentage of volatile matter. Therefore the coal from Tahoua will be more thermally efficient with non-smoky hot flame, while that of Enugu is less combustible, and it burns with smoky flame.

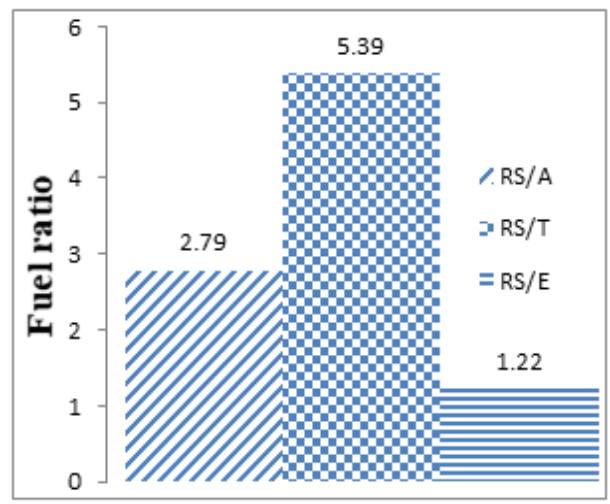

Fig 1: Fuel ratio of coal samples

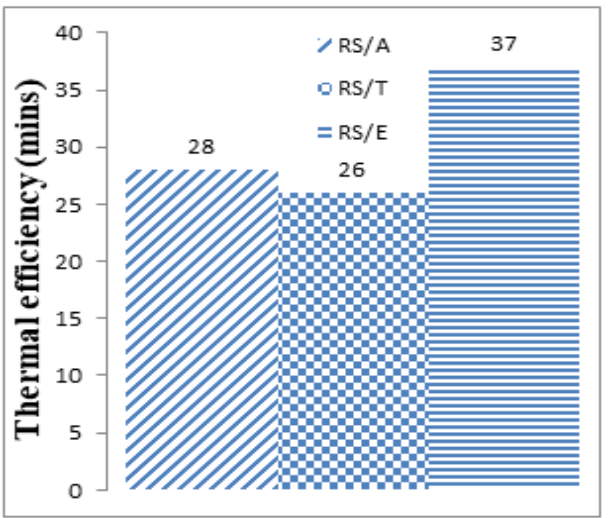

Fig 2: Thermal efficiency of coal samples

Sulphur content of the coal: Result of chemical analysis of forms of Sulphur (Table 2) shows percentage of pyritic Sulphur was highest $(3.65 \%)$ in sample from Agadez (RS/A) followed by sample from Tahuoa (RS/T), 2.39\% and then sample from Enugu (RS/E), $0.29 \%$. While RS/T shows highest percentage of organic Sulphur $(1.86 \%)$ and RS/E had the lowest $(0.36 \%)$. Similarly, it is well known that the high amount of Sulphur in coal has an adverse influence on its utilisation and that it contributes to environment contamination, causing in effect acid rains (Feèko et al., 1991 and 1994). Therefore there is need to reduce the amount of Sulphur in the coals in order to make the coal environmentally friendly and safe for domestic usage.

\begin{tabular}{cllll} 
Table 2: Result of ultimate analysis in wt\% of the coal samples \\
\cline { 2 - 4 } Sample & Total & Pyritic & Sulfate & Organic \\
& Sulphur & Sulphur & Sulphur & Sulphur \\
\hline RS/A & 4.20 & 3.65 & 0.34 & 0.54 \\
RS/T & 4.43 & 2.39 & 0.18 & 1.86 \\
RS/E & 0.83 & 0.29 & 0.12 & 0.36 \\
\hline
\end{tabular}

Conclusion: The study was carried out to determine the suitability of coal from Nigeria and Niger mining sites for domestic energy use in order to reduce deforestation and negative climatic changes. One sample from Enugu Nigeria was selected and analysed along with the samples from Niger. The coal from Taohau was found to have higher percentage of fixed carbon and fuel ratio, thus, making it to be the most combustible, followed by the coal from Agadez and lastly, coal from Enugu.

\section{REFERENCES}

Annual Book of ASTM Standards, (1979). Part 26, Methods D2492-79 and D3177-75, American Society of testing materials, Philadelphia, PA.

Fawkes, H (2005). Energy efficiency in South African industry. J. of Eng. in South Afr. 16 (4): 18-25.

Obaje, NG (2009). Geology and Mineral Resources of Nigeria. Springer, pp. 220. 
Ogunsola, OI (1990). History of Energy Sources and Their Utilization in Nigeria. En. Sources. 12: 181198.

Fecko, P (1991). Desulphurization of coal from Northern Bohemian brown coal basin by bacterial leaching. Fuel. 70: 1187-1191.

Fecko, P (1996). Bacterial Desulphurization of coal from open pit Mine Michal. 5th. Southern Hemisphere Meeting on Mineral technology, INTEMIN, Buenos Aires, 1994, pp. 249-252.

American Society for Testing and Materials (2007). Annual Book of Standards, D2492-02, Standard Test Methods for Forms of Sulphur in Coal, American Society for Testing and Materials, Pennsylvania.
Klein, J; Van, AM; Pfeifer, F; Schacht, S (1994). Microbial Desulfurization of Coal and Oil. Fuel Proc. Tech. 40 (2-3): 297-310.

Blake, GR; Hartage, KH (1986). Bulk Density, In A. Klute, Ed., Methods of Soil Analysis, part I, physical and mineralogical methods. Agronomy monograph, 2nd Edi, pp. 363-375.

Constanti, M; Giralt, J; Bordons, A (1994). Desulphurization of Dibenzothiophene by Bacteria. World J. of Microb \& Biotech. 10(5): 510-516. 